\title{
INNOVATION ACTIVITY AND TECHNOLOGY TRANSFER OF HIGHER EDUCATION
}

\author{
Dr Liudmila Romanovich* \\ Belgorod State Technological University named after V.G. Shukhov, Russia \\ Dr Vladimir Sevostyanov \\ Belgorod State Technological University named after V.G. Shukhov, Russia \\ Marina Romanovich \\ Belgorod State Technological University named after V.G. Shukhov, Russia \\ Maxim Sevostyanov \\ Belgorod State Technological University named after V.G. Shukhov, Russia \\ Alexander Yakovlevich Arkatov \\ Belgorod State Technological University named after V.G. Shukhov, Russia
}

In an entry consider a current question of innovation activity institution of higher education in Russia, the role and place of youth in the further progressive development of our society [01, 04]. The generalized and analyze an experience innovation activity of Belgorod State Technological University named after V.G Shukhov in variously trending of academic process; scientific public private partnership with educational structure and the business community; and competitive growth of specialists in the labor market. As exemplified by created a scientific-innovative platform shows the role of small, innovative companies in the preparation of highly qualified specialists and realize the creative potential of youths [02].

Key words: Innovative activity, Educational research and innovation complex, Innovation and Technology Center, Business incubator, Small innovative companies, Innovation belt, Higher educational institutions, Young scientists, Prototype model, Technology, International technology park.

Economic recovery and positive changes in economic structure of primarily at first instance adjacent with a large-scale utilization of scientific and technological advancements. Achievement sustained growth and improving national competitiveness is a complex task, the success of which is determined by the development of economic institutions and the creation of new competitive position. In the future, sustainable economic growth will depend on the development and policy implementations aimed at the active use of knowledge as the basis for the development process. The utmost able to meet competition economy in which knowledge and innovation are created, distributed and used effectively. The transition to an innovative economy socially-oriented model of development is one of the priority areas for further improvement of the economy, science and industry of our country. The only possible way to achieve these goals is to move the economy to an innovation social -oriented model of development. Today, Russia is at an important stage in its economic, political and social development. A major participant in this process and should be, in fact, is becoming the Russian youths. They are the most active constituent of civil society: the young people are better adapted to the implementation of innovative projects and technologies in variety of fields, they are concentrating fundamentally new knowledge and ideas, they are mobile and full of energy to build their lives. As to self-concept, that the young people constitute oneself a prime factor of sustainable development of Russia and most of them - the driving force of radical transformations in society. Russian youth - the head customer of a future worth living, the main strategic resource of the country $[02,10]$. At the present time, Higher education of countries are increasingly acting as a level of interest in the development of public-private partnership in the realm of science, education and innovative technology; create expanded structure of small innovation company (SIC), which malleable to market demands on a high technology products. The university object infrastructure support innovation perform a wide spectrum of functions, the 
most important of which are the development of different forms of cooperation among universities, development laboratories, industry and business, as well as assistance to firms in coupling new ideas to commercialization $[10,09]$. In Russia, the seed stage companies basis on universities to occur in order to commercialize innovative technologies developed in universities. Copyright of the results of intellectual activity (RIA) are universities. For educational institutions, conducting research from public accounts budget resources, the legal environment of commercialization RID is critically needed. It should be noted that the Federal Law № 209-FZ of July 24, 2007 "On the development of small and medium enterprises in the Russian Federation" and the number 217-FZ of August 2, 2009. "On amendments to certain legislative Acts of the Russian Federation on the establishment budget scientific and educational institutions, business entities with a view to practical application (implementation) of the results of intellectual activity" contributed to the dynamic growth of small innovative enterprises. The main purpose of these laws is to promote the real implementation of RIA created in production, the exclusive rights to which belong to budgetary institutions of science and education. At the present time, Russia has a number of universities, successfully developing innovation and implementing innovation modern instruments to stimulate innovation. Among them - Belgorod State Technological University named after V.G. Shukhov is take up a station in regard of innovative young scientists.
The University is actively involved in the formation on the basis of its innovative infrastructure. The purpose of the implementation of this concept - creating a single educational research and innovation space, which aims to involve young people in innovation. In such a way formed and rapidly developing effective educational model research and innovation complex, as a result of which in recent years has significantly increased activity students, doctoral students and researchers. As a result, the main universities become a basic element of scientific and educational innovation platforms, which include department, research laboratories and small innovative enterprises, created with the participation of scientists, as well as graduate students and doctoral candidates [07, 08]. As a result, research and education, innovative platform provides a full cycle of excellence, generates new knowledge, innovations, issue an innovative products. The critical influence in the implementation of the model of scientific innovation activities at the university operates two innovative zones, actively cooperation with each other, that permits to bring off the object in view and responsibilities.

Innovation First zone - is an academic innovation platforms (at the University created 20 such platforms) and object of infrastructure support to small innovative companies in the early stages of their development - Innovation and Technology Centre. The last zone carries out complex projects: "Innovative business incubator", "Business Center", "School of entrepreneurship education in high-tech", etc.

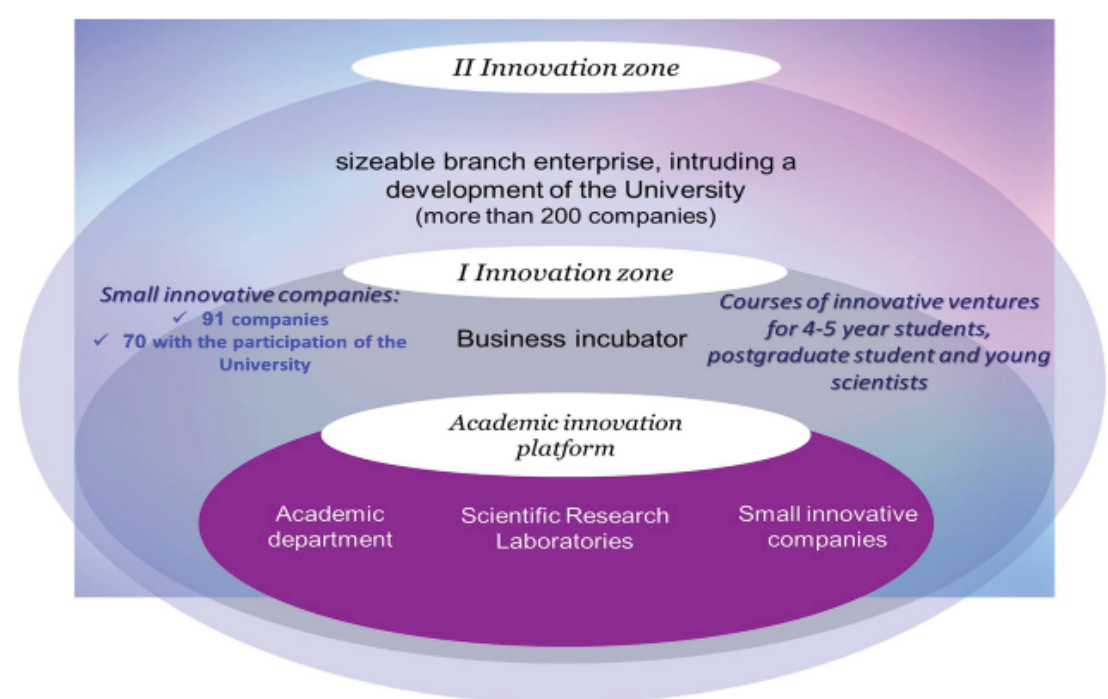

Figure 1: The mechanism for the implementation of innovation activity of the University [04] 
Today, 91 small innovative enterprises, including 70 under the Federal Law 217-FZ are using the services of "Innovative Business Incubator". The registered capital of these enterprises includes the right to use the intellectual property of the university: inventions, utility models and software. These companies operate in the field of energy saving, information technology, nanotechnology, new materials and equipment: "Innovative technologies and machine building equipment", "Rostechceram", "Recycle-Intech", "NTC Modern integrated automation techniques," "BetonProekt", LLC "Modern corporate systems", "FITIntellect", "BelSilica", "Center for Energy Saving Technologies", "Building Complex", and others. Innovative small businesses receive scientific and consulting support in the framework of "Business Center" project and learn the basics of innovative entrepreneurship in the "School of entrepreneurship education in the field of high technology".

The Second innovation zone is represented by BSTU International Technology Park, bringing together about 200 leading manufacturing companies and business in Russia and abroad. It provides support for scientists in introducing innovations in the industry, facilitates the transfer of technology from the university science into the industrial sector [03, 05]. As a result of active implementation of the mechanism of development of educational research and innovation complex in 2013 the university implemented 94 projects through innovative structures (compared to 14 in 2008), 517 students were involved in innovative projects (130 in 2008), 73 licensing agreements were concluded with enterprises (in 2008 - 6), 489 university-based jobs for young scientists and students have been created [06]. An important component of the innovative development of the university is a public-private partnership with various educational institutions, enterprises (companies, holding companies), and business structures of various professional orientations corresponding to the profile of the higher education institution.

This allows solving a number of topical innovation tasks:

- To implement a number of innovative projects in the area of continuing professional education (high schools, colleges, private institutions Highest vocational education, example Belgorod Engineering economical institute, additional vocational training, etc.);

- Strengthen professional training through the implementation of the educational process in the real production (creating basic departments in enterprises, organization of training on it applied bachelor's degree designing and UNIRS on problematic tasks of production, etc.);

- Expand the range of activities in the promising areas IIP development of business structures (creation of resource energy saving technological complexes for production of high-tech building materials and products, including individual housing complex processing of industrial materials and products and the development of wholesome production, innovation information technology, etc.);

- Increase the competitiveness of university graduates in the labor market by expanding the scope of cooperation with employers and provide them with feedback (implementation developed at the University of the automated system of graduate employment - project "Scilbook» with the creation of "competency portfolio" graduate), etc.

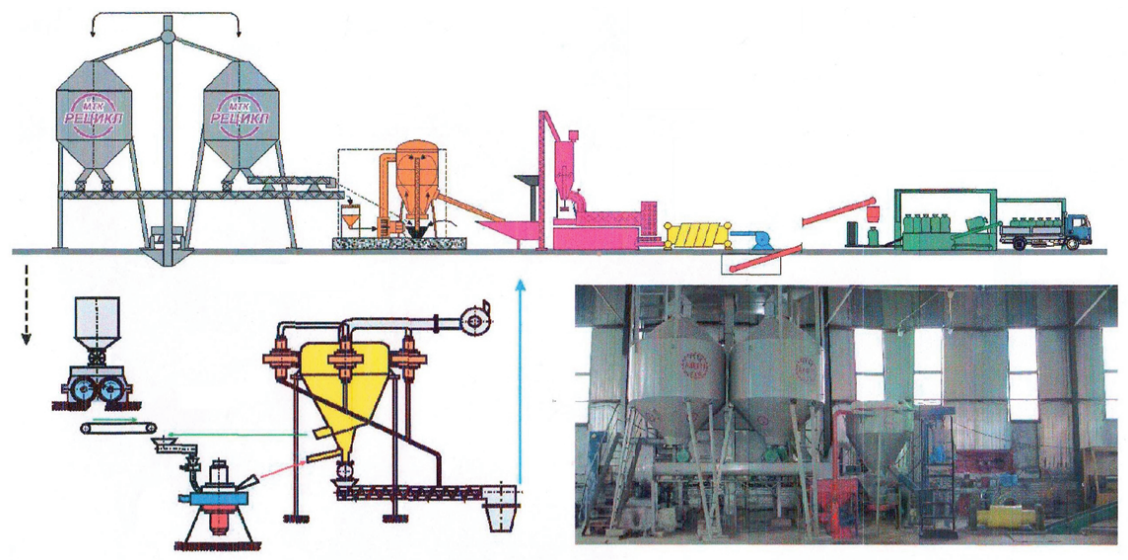

Figure 2: Multifunctional technological complex for the production of mechanically activated composite mixtures and compacted materials 


\section{CONCLUSION}

At the present time, BSTU named after V.G. Shukhov is an active partner in the development of innovative systems of Higher education at the regional and federal level. According to the rating of Federal Education Agency for several years BSTU named after V.G. Shukhov ranks first among the architectural and engineering Universities in Russia. Following the results of independent monitoring Institutions of Higher Education by public organizations, BSTU named after V.G. Shukhov is among the sixteen best Russian higher educational institutions on the quality of training, the demand for graduates and their active career.

\section{SUMMARY}

Implementing only one of the directions of innovative development - the establishment of effective technological multifunctional complexes based SIB provides university variety of advantages:

- Accelerated implementation of scientific ideas from conception, tender evaluation prior to implementation;

- Interdepartmental interaction of scientists in promising areas of activity involving students and young scientists;

- Temporary employment of students during industrial practice and employment of graduates of university - based research and industrial production;

- Organization of training, retraining and advanced training of specialists in various fields of science and production and business activities;

- Duplication of research and development (design documentation, designs, modeling and development of industrial designs the patented equipment) in the industrial sector of small and medium-sized businesses, etc.

\section{ACKNOWLEDGEMENTS}

The authors extend acknowledgements to the rector of BSTU, prof. Sergei Nikolaevich Glagolev for their assistance in organizing the study and publication of the results. Work has been performed in the framework of Strategic Development Program at BSTU for 2012-2016.

\section{REFERENCES}

1) Marcus, C. (2005): Future creative industries - orientations for policy research, Working Paper of the European Commission, EUR 21471.
2) On Strategy of Innovation Development of the Russian Federation for the period up to 2020 (2011), Order of the Government of the Russian Federation of December, No 2227.

3) Pererva, P.G., Glagolev, S., Mehovich, S., Sevostiyanov, V. (2012) Fundamentals of Innovation Management and Economics of Innovation. Tutorial. Part II. Management research. Marketing and commercialization of innovations, Belgorod State Technological University named after V.G. Shukhov.

4) Pererva, P.G., Glagolev, S., Mehovich, S., Sevostiyanov, V. (2012) Fundamentals of Innovation Management and Economics of Innovation. Tutorial. Part I. Innovation management, Belgorod State Technological University named after V.G. Shukhov.

5) Pererva, P.G., Glagolev, S., Mehovich, S., Sevostiyanov, V. (2012) Fundamentals of Innovation Management and Economics of Innovation. Tutorial. Part III. The organization of training for the innovation economy, Belgorod State Technological University named after V.G. Shukhov.

6) Romanovich, L.G., Rudichev, A., Romanovich, M., Lycheva, A. (2013): Incentives for Innovative Activity of Young Scientists on the Basis of Higher Educational Institutions in Russia. Experience of Belgorod State Technological University named after V.G. Shukhov, World Applied Sciences Journal, No 25, pp. 1754-1757.

7) Romanovich, M.A., Evtushenko, E., Romanovich, L. (2013): Promoting innovation youth on the basis of higher education institutions, Bulletin of Belgorod State Technological University named after V.G. Shukhov, No 5, pp. 150-152.

8) Romanovich, M.A., Rudychev, A., Romanovich, L. (2011): Venture investment in innovative enterprises abroad and in Russia, Bulletin of Belgorod State Technological University named after V.G. Shukhov, No 4, pp.123-126.

9) Sevostyanov, V.S, Ilina, N., Sevostyanov, M., Shkarpetkin, E. (2011): Study of process a microgranulation in disperse systems. Bulletin of Belgorod State Technological University named after V.G. Shukhov, (1): 81-86.

10) Sevostyanov, V.S, Romanovich, A.A., Platonov ,V.S., Kozko, V.P, The press-roll coal, Invention patent RUS № 2030213.

Paper sent to revision: 05.11.2014.

Paper ready for publication: 15.12.2014. 